\title{
IgG4-related disease presenting with headache and papilloedema
}

\author{
Eva Patrícia Lourenço, ${ }^{1}$ Hipólito Nzwalo, ${ }^{1}$ Mário Rui Sampaio, ${ }^{2}$ Luís Afonso ${ }^{1}$
}

${ }^{1}$ Centro Hospitalar do AlgarveHospital de Faro, Faro, Portugal

${ }^{2}$ Centro de Saúde de Tavira, Tavira, Portugal

\section{Correspondence to} Dr Eva Patrícia Lourenço, evalour2004@gmail.com

Accepted 17 October 2016
CrossMark

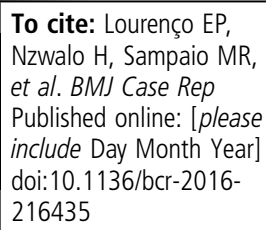

\section{DESCRIPTION}

A previously healthy man aged 57 years presented with a 4-week duration of predominant decubitus daily holocranial headache after minor head injury. Apart from unintentional weight loss of 8 pounds, there were no associated constitutional or systemic manifestations. The general and neurological examination was unremarkable. The funduscopy showed bilateral grade 2 papilloedema. Brain magnetic resonance (MRI) findings are shown in figure 1A-E. The brain MRI showed the presence of diffuse dural thickening (figure 1B-E) hypointense on unenhanced T1 imaging (figure 1B-F), with dural enhancement on T1-weighed imaging (figure 1B-F). The opening cerebrospinal fluid (CSF) pressure was $380 \mathrm{~mm} \mathrm{Hg}$. With the exception of serum-elevated IgG4 immunoglobulin (IgG4 $=302 \mathrm{mg} / \mathrm{dL}$ ) and elevated CSF protein level $(68 \mathrm{mg} / \mathrm{dL})$, the wide and extensive complementary study including body positron emission tomography scan, laboratory blood/CSF work-up was negative, excluding neoplastic, infectious, autoimmune and collagen vascular disorders. Meningeal biopsy showed fibrous thickening with moderate and predominant $\mathrm{B}$ and $\mathrm{T}$ cells inflammatory infiltrate. The patient improved with spinal taps evacuation and methylprednisolone treatment.
Intracranial hypertrophic pachymeningitis is a severe and rare manifestation in the spectrum of IgG4-related diseases. ${ }^{1}{ }^{2}$ Biopsy of meninges is the gold standard for the diagnosis. ${ }^{3}$ Exclusion of systemic inflammatory disorders and demonstration elevated serum IgG4 can support the diagnosis in patients with typical diffuse dural thickening. ${ }^{13}$ The disease responds to immunosuppressive drugs such as corticosteroids, methotrexate, azathioprine, mycophenolate or cyclophosphamide. ${ }^{12}$ Mass effect due to dural thickening can cause progressive neurological debilitation, blindness and cerebellar ataxia. In the case of symptomatic hydrocephalus, surgical exploration for decompression may be required. ${ }^{1-3}$

\section{Learning points}

- Intracranial hypertrophic pachymeningitis is a severe and rare manifestation in the spectrum of IgG4-related diseases.

- The disease responds to immunosuppressive drugs such as corticosteroids, methotrexate, azathioprine, mycophenolate or cyclophosphamide.

Figure 1 Sagittal (A) T1-weighed imaging showing the presence of diffuse meningeal thickening. On sagittal $(B, C)$ and posterior to anterior coronal (D-F) gadolinium-enhanced T1-weighed imaging, there is marked infratentorial and supratentorial diffuse meningeal enhancement.

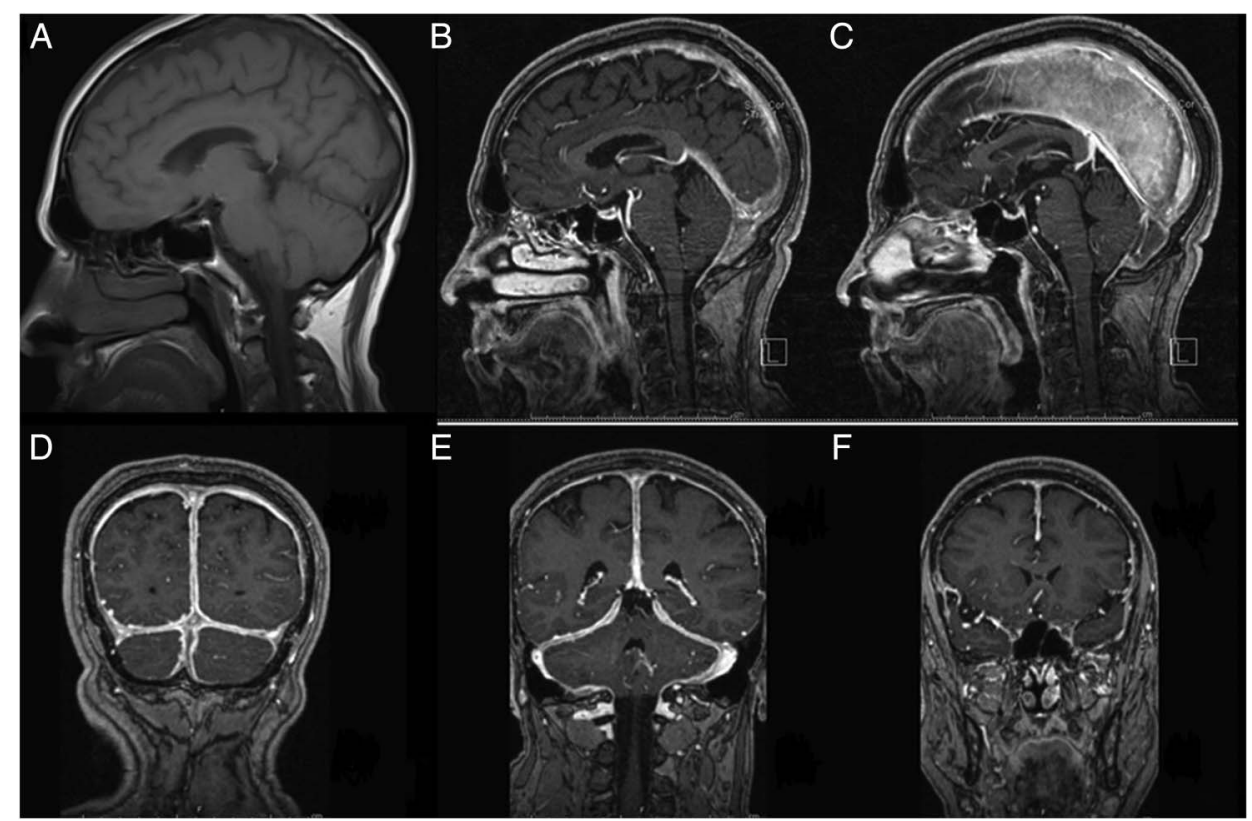


Contributors EPL and MRS contributed to scientific research, and analysis and interpretation of similar cases reported before. EPL and HN contributed to interpretation of the collected data and drafting the work and revising it.

Competing interests None declared.

Patient consent Obtained.

Provenance and peer review Not commissioned; externally peer reviewed.

\section{REFERENCES}

1 Vasaitis L. IgG4-related disease: a relatively new concept for clinicians. Eur J Intern Med 2016;27:1-9.

2 Lu LX, Della-Torre E, Stone JH. IgG4-related hypertrophic pachymeningitis: clinical features, diagnostic criteria, and treatment. JAMA Neurol 2014;71:785-93.

3 Lindstrom KM, Cousar JB, Lopes MB. IgG4-related meningeal disease: clinico-pathological features and proposal for diagnostic criteria. Acta Neuropathol 2010;120:765-76.

Copyright 2016 BMJ Publishing Group. All rights reserved. For permission to reuse any of this content visit http://group.bmj.com/group/rights-licensing/permissions.

BMJ Case Report Fellows may re-use this article for personal use and teaching without any further permission.

Become a Fellow of BMJ Case Reports today and you can:

- Submit as many cases as you like

- Enjoy fast sympathetic peer review and rapid publication of accepted articles

- Access all the published articles

- Re-use any of the published material for personal use and teaching without further permission

For information on Institutional Fellowships contact consortiasales@bmjgroup.com

Visit casereports.bmj.com for more articles like this and to become a Fellow 